\title{
Vegetative development and yield of the banana cv. 'Prata Anã' as a function of magnesium and potassium fertilization
}

\author{
Desarrollo y producción del banano 'Prata Anã' bajo \\ fertilización con magnesio y potasio \\ Inêz Pereira da Silva ${ }^{1 *}$, José Tadeu Alves da Silva², Paulo Jorge de Pinho ${ }^{1}$, \\ Cleber Lázaro Rodas ${ }^{1}$, Janice Guedes de Carvalho ${ }^{1}$
}

\begin{abstract}
To apply high amounts of $\mathrm{K}$ to the soil there must be adequate quantities of $\mathrm{Mg}$, thus avoiding the rise of physiological disorders in the banana plant which appear as Mg-induced deficiency symptoms. The purpose of this study was to evaluate the effects of application of $\mathrm{K}$ and $\mathrm{Mg}$ on the vegetative development and yield of the banana cv. "Prata Anã'. Treatments were distributed in a randomized block design in a $3 \times 5$ factorial arrangement, corresponding to three doses of potassium $\left(0,800\right.$ and $1200 \mathrm{~kg} \mathrm{ha}^{-1}$ year $\left.{ }^{-1}\right)$ and five doses of magnesium $\left(0,60,120,240\right.$ and $480 \mathrm{~kg} \mathrm{ha}^{-1}$ year-1 $\left.^{-1}\right)$, with three replicates. The sources of potassium and magnesium were potassium chloride and magnesium sulfate, respectively. Application of $\mathrm{K}$, regardless of the cycle, increased the bunch weight, the number of banana fruits per bunch, the number of hands per bunch, and the weight and diameter of the middle fruit of the banana plant. Increasing doses of $\mathrm{Mg}$ applied to the soil reduced the weight of the bunch in the first cycle; and with increasing doses of $\mathrm{K}$ there was an increase in the leaf content of $\mathrm{K}$ and $\mathrm{Ca}$, with a decrease in the leaf content of $\mathrm{Mg}$ and $\mathrm{B}$ in the banana cv. 'Prata Anã'.
\end{abstract}

Key words: Musa sp., mineral nutrition, nutritional balance.

\section{RESUMEN}

Para que sean aplicadas grandes cantidades de K en el suelo, hay necesidad que los niveles de Mg sean adecuados en lo mismo, evitando así la aparición de desórdenes fisiológicos en el banano, expresado en los síntomas de deficiencia inducida de $\mathrm{Mg}$. El objetivo de este estudio fue evaluar los efectos de la aplicación de $\mathrm{K}$ y $\mathrm{Mg}$ en el desarrollo y la productividad del banano'Prata Anã'. Los tratamientos se dispusieron en un diseño de bloques al azar con un factorial $3 \times 5$, que corresponden a tres niveles de potasio (0, 800 y $1200 \mathrm{~kg} \mathrm{ha}^{-1}$ año $o^{-1}$ y cinco dosis de magnesio (0, 60, 120, 240 y $480 \mathrm{~kg} \mathrm{ha}^{-1}$ año $)$, con tres repeticiones. Las fuentes de potasio y magnesio fueron, respectivamente, cloruro de potasio y sulfato de magnesio. La aplicación de K, independiente del ciclo, aumentó el peso del racimo, número de frutos por racimo, el número de manos por racimo, la masa y el diámetro del fruto central de la banana. Dosis crecientes de Mg aplicadas al suelo reducen la masa del racimo en el primer ciclo. Con el incremento de las dosis de K hubo un aumento en $K$ y Ca foliar, con una reducción en Mg y $B$ foliar del banano 'Prata Anãa'.

Palabras clave: Musa sp., nutrición mineral, equilibrio nutricional.

\section{Introduction}

The banana plant is sensitive to nutritional imbalance, and to raise its yield and improve fruit quality it is important to maintain balance among the nutrients in the soil. This therefore avoids that greater uptake of one element occurs, inducing deficiency of another, which would lead to the appearance of physiological disorders in the plant, also making it more susceptible to the attack of pests and organisms that cause harm (Silva and Borges, 2008).

Potassium (K) is the nutrient most highly taken up by the banana plant and it is found in high quantities in the plant. This nutrient has an important function in the energy state, in translocation and storage of photoassimilates and in maintaining water in plant tissues, and it is essential for the

1 Departamento de Ciência do Solo - Universidade Federal de Lavras, Campus UFLA, Lavras- MG, Brasil. Caixa Postal $3037-$ CEP 37.200-000.

2 Empresa de Pesquisa Agropecuária de Minas Gerais - EPAMIG/ CTNM.

* Corresponding author: inezps@yahoo.com.br 
growth, development and ripening of fruit. To obtain high yield and good quality fruit, the banana plant requires the application of high doses of $\mathrm{K}$. The quantities of $\mathrm{K}$ applied to the soils of various banana-producing countries range from 100 to 1,200 $\mathrm{kg}$ of $\mathrm{K}_{2} \mathrm{O}$ ha $^{-1}$ year $^{-1}$.

Nevertheless, Silva et al. (1999) showed that the positive effect of applying high doses of K only occurs when calcium (C) and magnesium $(\mathrm{Mg})$ amounts are adequate in the soil. Specifically in the case of $\mathrm{Mg}$, its main functions in the plant are to act as an activator of a large number of enzymes, participate in the structure of chlorophyll and to be a P transporter (Vitti et al., 2006). In the case of $\mathrm{Mg}^{2+}$ deficiency, there is reduction in chlorophyll synthesis, and consequently in the photosynthetic rate. Silva et al. (2008), working with application of $\mathrm{K}, \mathrm{Mg}$ and lime in plantlets of the banana cv. "Prata Anã', observed that the Mg content decreased in a quadratic manner with the increase in doses of $\mathrm{K}$ applied to the soil, with or without application of lime, showing the antagonism existing between $\mathrm{K}$ and $\mathrm{Mg}$. Therefore, so that high amounts of $\mathrm{K}$ may be added to the soil, it is necessary for $\mathrm{Mg}$ to be at adequate levels, thus avoiding the appearance of physiological disorders in the banana plant (Silva et al., 1999).

The purpose of this study was to evaluate the effects of application of $\mathrm{K}$ and $\mathrm{Mg}$ on the development and yield of the irrigated banana cv. "Prata Anã' in two production cycles.

\section{Materials and Methods}

The experiment was conducted from 2007 to 2009 at the Experimental Farm of the Empresa de Pesquisa Agropecuária de Minas Gerais (EPAMIG) (Crop and Livestock Research Company of Minas Gerais) in the municipality of Jaíba, MG, Brazil. The soil was classified as a clayey texture Red Latosol (RL) (Embrapa, 1999), whose chemical and granulometric characteristics are given in Table 1.
For installation of the experiment, banana cv. 'Prata Anã' plantlets were obtained from tissue culture. Furrows with a spacing of $3.0 \mathrm{~m}$ between them were opened, and along them, hills of $10 \mathrm{~cm} \times 10 \mathrm{~cm}$ were opened at a spacing of $2.7 \mathrm{~m}$. Treatments arose from a 3 x 5 factorial arrangement, corresponding to three does of potassium $\left(0,800\right.$ and $1200 \mathrm{~kg} \mathrm{ha}^{-1}$ year $\left.{ }^{-1}\right)$ and five doses of magnesium $(0,60,120$, 240 and $\left.480 \mathrm{~kg} \mathrm{ha}^{-1} \mathrm{year}^{-1}\right)$, and were distributed in randomized blocks with three repetitions. Each plot consisted of 15 families with a useful area of 3 families. The potassium and magnesium sources were potassium chloride and magnesium sulfate respectively.

In the plant hill, phosphorus was applied in the form of MAP as a constant factor. Fertilization for plant growth and fruit production were applied monthly in a manual fashion in a semicircle at $40 \mathrm{~cm}$ distance from the plants. To perform this fertilization, urea, zinc sulfate and boric acid were used as sources of nitrogen, zinc and boron as recommended by Silva et al. (1999).

At the beginning of emergence of the bunches of the mother and daughter plants in each useful plot, the height and diameter of the pseudostem were evaluated at $30 \mathrm{~cm}$ from the soil surface. Upon reaching the harvest stage, the bunches of the useful banana plants from each plot were gathered, dehanded and weighed. The number of banana fruits per bunch, the number of hands per bunch, and the weight, mean length and diameter of the fruit of the second hand of each bunch were assessed.

In plants initiating emergence of the bunch the third leaf from the apex was collected, from which $10 \mathrm{~cm}$ of the center of each leaf blade was removed, eliminating the midrib. The collected material was washed in distilled water and then dried in a forced air circulation laboratory oven at $70{ }^{\circ} \mathrm{C}$ for 72 hours. The material, after drying, was ground for determination of nutrients, according to the methodology described by Malavolta et al. (1997).

Table 1. Chemical and granulometric soil attributes before planting at a depth of $0-20 \mathrm{~cm}$.

\begin{tabular}{|c|c|c|c|c|c|c|c|c|c|c|c|c|}
\hline Soil & $\mathrm{pH}$ & $\mathrm{P}$ & K & $\mathrm{Ca}$ & $\mathrm{Mg}$ & $\mathrm{CEC}^{1}$ & $\mathrm{~V}^{2}$ & P-rem ${ }^{3}$ & $\mathrm{OM}^{4}$ & Clay & Silt & Sand \\
\hline \multicolumn{4}{|c|}{$\mathrm{mg} \mathrm{dm^{-3 }}$} & \multicolumn{3}{|c|}{$\mathrm{cmol}_{\mathrm{c}} \mathrm{dm}^{-3}$} & $\%$ & $\mathrm{mg} \mathrm{L}^{-1}$ & \multicolumn{4}{|c|}{ dag kg-1 } \\
\hline RL & 6.1 & 3.3 & 128 & 6.5 & 1.6 & 11.0 & 78 & 18.4 & 2.4 & 50 & 29 & 21 \\
\hline
\end{tabular}

${ }^{1}$ Cation-exchange capacity; ${ }^{2}$ Base saturation; ${ }^{3}$ Remaining phosphorus; ${ }^{4}$ Organic matter. 
Data were submitted to the Bartlett test $(P<0.05)$ and then analysis of variance (ANOVA, $P<0.05$ and $P<0.01)$ and polynomial regression $(P<0.05)$, using the SOC statistical package (Embrapa, 1990).

\section{Results and Discussion}

Analysis of variance for yield and height of the banana cv. 'Prata Anã' (Table 2) showed significant effect $(P<0.01)$ between cycles for all the variables except for length of the middle fruit (CFC). For the doses of $\mathrm{K}$, there was a significant effect on the number of fruits per bunch (NFC), with interaction between the cycle and the doses of K for NFC and the number of hands per bunch (NPC). The weight of the middle fruit (MFC) and the diameter of the middle fruit (DFC) showed a significant effect $(P<0.05)$ for the doses of $\mathrm{K}$.

The weight of the bunch in the first cycle increased in a quadratic manner, and in the second cycle in a linear manner with increase in the doses of $\mathrm{K}$; however, it decreased in a quadratic manner with increase in the doses of $\mathrm{Mg}$ in the first cycle. In the second cycle, in the absence of potassium fertilization, the weight of the bunch increased in a linear manner with increase in the doses of $\mathrm{Mg}$ (Figures 1a and 1b).

Similar results were found by Brasil et al. (2000), who observed that nitrogen and potassium fertilization produced an increase in the weight of the bunch, number of hands per bunch and average

Table 2. Summary of analysis of variance for height, number of fruit per bunch (NFB), number of fruit per hand (NFH), number of hands per bunch (NHB), central fruit weight (CFW), central fruit length (CFL) and central fruit diameter (CFD) of banana 'Prata Anã' in two production cycles for different $\mathrm{K}$ and $\mathrm{Mg}$ concentrations applied in the soil.

\begin{tabular}{|c|c|c|c|c|c|c|c|c|}
\hline \multirow{2}{*}{ Variation sources } & \multirow{2}{*}{ DF } & \multicolumn{7}{|c|}{ Mean Squares } \\
\hline & & height $^{(1)}$ & NFB & $\mathrm{NFH}^{(1)}$ & NHB & CFW & CFL & CFD \\
\hline Cycle (CL) & 1 & $466.3659^{\text {** }}$ & $305778.84^{* *}$ & $128.68^{* *}$ & $15.90^{* *}$ & $22098.14^{* *}$ & $23.29^{\mathrm{ns}}$ & $1.930^{\text {** }}$ \\
\hline Magnesium (Mg) & 4 & $0.0241 \mathrm{~ns}$ & $39.70^{\mathrm{ns}}$ & $0.022^{\mathrm{ns}}$ & $0.09^{\mathrm{ns}}$ & $367.05^{\mathrm{ns}}$ & $10.14^{\mathrm{ns}}$ & $0.173^{\mathrm{ns}}$ \\
\hline Potassium $(\mathrm{K})$ & 2 & $0.0728^{\mathrm{ns}}$ & $408.99^{* *}$ & $0.001 \mathrm{~ns}$ & $0.22^{\mathrm{ns}}$ & $1487.11^{*}$ & $23.21^{\mathrm{ns}}$ & $0.302^{*}$ \\
\hline $\mathrm{CL} * \mathrm{Mg}$ & 4 & $0.0274^{\mathrm{ns}}$ & $36.32^{\mathrm{ns}}$ & $0.008^{\mathrm{ns}}$ & $0.36^{\mathrm{ns}}$ & $129.55^{\mathrm{ns}}$ & $5.16^{\mathrm{ns}}$ & $0.068^{\mathrm{ns}}$ \\
\hline $\mathrm{CL} * \mathrm{~K}$ & 2 & $0.0735^{\mathrm{ns}}$ & $390.28^{* *}$ & $0.003^{\mathrm{ns}}$ & $1.41^{* *}$ & $472.02^{\mathrm{ns}}$ & $7.50^{\mathrm{ns}}$ & $0.119^{\mathrm{ns}}$ \\
\hline $\mathrm{Mg} * \mathrm{~K}$ & 8 & $0.0207^{\mathrm{ns}}$ & $20.45^{\mathrm{ns}}$ & $0.011^{\mathrm{ns}}$ & $0.42^{\mathrm{ns}}$ & $625.57^{\mathrm{ns}}$ & $6.644^{\mathrm{ns}}$ & $0.078^{\mathrm{ns}}$ \\
\hline $\mathrm{CL} * \mathrm{Mg} * \mathrm{~K}$ & 8 & $0.0207^{\mathrm{ns}}$ & $19.78^{\mathrm{ns}}$ & $0.009^{\mathrm{ns}}$ & $0.25^{\mathrm{ns}}$ & $215.10^{\mathrm{ns}}$ & $7.10^{\mathrm{ns}}$ & $0.070^{\mathrm{ns}}$ \\
\hline Residual & 60 & 0.0242 & 52.11 & 0.016 & 0.25 & 360.71 & 7.54 & 0.075 \\
\hline Average & - & 133.82 & 60.55 & 71.86 & 8.60 & 130.04 & 17.58 & 3.57 \\
\hline V.S. $_{\text {exp. }}(\%)$ & - & 5.44 & 11.92 & 5.34 & 5.91 & 14.60 & 15.62 & 7.70 \\
\hline
\end{tabular}

ns not significant value at $5 \%$ of probability by $\mathrm{F}$ test. ${ }^{*}$ and ${ }^{* *}$ significant value at $5 \%$ and $1 \%$ probability by $\mathrm{F}$ test, respectively. (1) Transformed data $(n / 10)^{0,5}$ by Hartley test at $5 \%$ of probability. DF = Degree of freedom, V.S. exp. $_{\text {. }}$ experimental coefficient of variation.
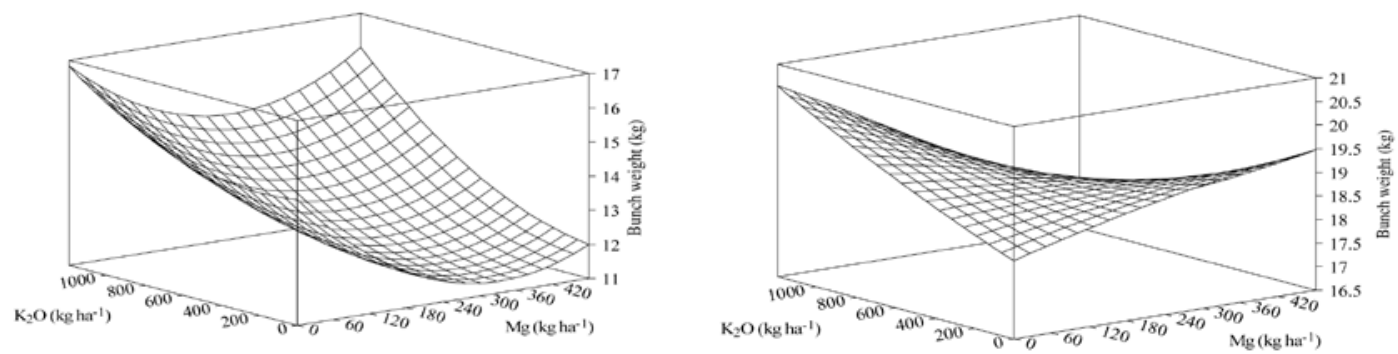

Figure 1. Weight of the bunch (kg) of the banana cv. "Prata Anã' in the first (a) and the second (b) production cycle as a function of doses of $\mathrm{K}$ and $\mathrm{Mg}$ applied on the soil. 
weight of the hand. However, Maia et al. (2003) did not find a positive effect of doses of $\mathrm{K}$ on the weight of the bunch and diameter of the fruit of banana cv. "Prata Anã'. Silva et al. (2003), studying the effect of $\mathrm{N}$ and $\mathrm{K}$ on the performance of banana cv. 'Prata Anã' in a Red-Yellow Latosol in the North of Minas Gerais (Brazil), observed a positive response to $\mathrm{K}$ only in the fourth production cycle, where a dose of $962.5 \mathrm{~kg} \mathrm{ha}^{-1}$ led to maximum yield, providing for an increase of $11.2 \%$ in banana yield in relation to the control. According to Ganeshamurthy et al. (2011), high K contents are necessary for achieving not only high total fruit yield, but also for the quality suitable for commercialization.

The banana bunch is the part of the plant must affected by the lack of K. Due to low supply of K, translocation of carbohydrates from the leaves to the fruit decreases, and even when the sugars reach the fruit, their conversion into starch is restricted, producing small fruit inappropriate for sale, with irregular maturation and pulp that is not very flavorful (Borges, 2004). Moreover, according to
Borges (2004), $\mathrm{K}$ and $\mathrm{N}$ are the nutrients most taken up and required for growth and yield of the banana plant, followed by $\mathrm{Mg}$ and $\mathrm{Ca}$.

The greatest $\mathrm{K}$ content in the banana leaves occurred with the application of the greatest dose of K (Figure 2). Silva et al. (2003) and Silva et al. (2008) observed that the application of increasing doses of $\mathrm{K}$ in the soil raised the $\mathrm{K}$ content in the leaves of the banana cv. 'Prata Anã'. According to Faquin (2005), the Mg concentration in the soil solution is generally greater than that of $\mathrm{K}$, but the $\mathrm{K}$ uptake rate is greater than that of $\mathrm{Mg}$.

The $\mathrm{Mg}$ leaf content decreased in a quadratic manner with increase in the doses of $\mathrm{Mg}$ applied to the soil in the first cycle (Figure 3a). The result obtained was different from that expected because with the increase in the doses of $\mathrm{Mg}$ applied to the soil, it was expected that there would be an increase in the leaf content of this element. To obtain high yield and good quality fruit, the banana plant requires a large quantity of $\mathrm{K}$. Large uptake of $\mathrm{K}$ may lead to translocation of $\mathrm{Mg}$ toward the fruit
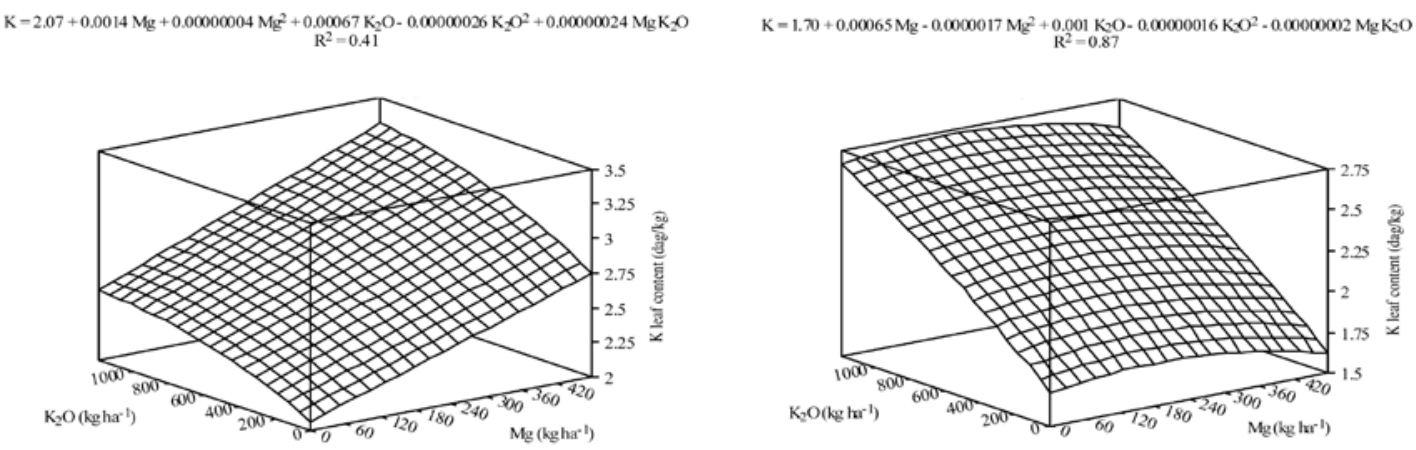

Figure 2. K leaf content in the first cycle (a) and in the second cycle (b) of the banana 'Prata Anã' as a function of doses of K and $\mathrm{Mg}$ applied to the soil.

$\mathrm{Mg}=0.48-0.00049 \mathrm{Mg}+0.00000057 \mathrm{Mg}^{2}+\underset{\mathrm{R}^{2}-0.00049}{0.004} \mathrm{~K}_{2} \mathrm{O}-0.00000002 \mathrm{~K}_{2} \mathrm{O}^{2}-0.00000012 \mathrm{MgK}_{2} \mathrm{O}$

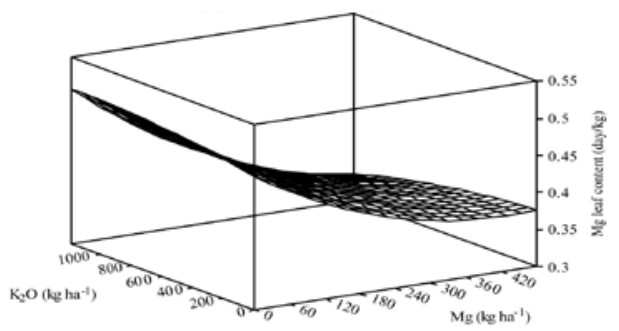

$\mathrm{Mg}=0.68+0.00024 \mathrm{Mg}-0.00000032 \mathrm{Mg}^{2}-0.000057 \mathrm{~K} \mathrm{R}_{2}^{2} \mathrm{O}-0.0 .00000012 \mathrm{~K}_{2} \mathrm{O}^{2}-0.00000003 \mathrm{MgK}_{2} \mathrm{O}$

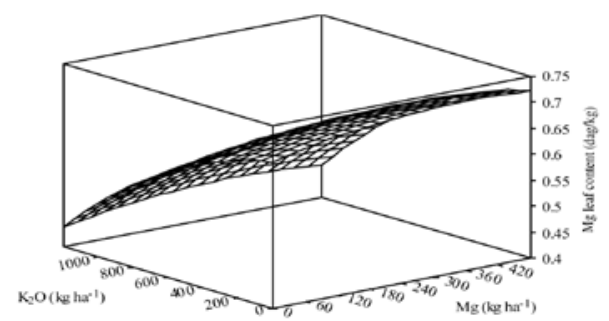

Figure 3. Mg leaf content in the first cycle (a) and in the second cycle (b) of the banana cv. 'Prata Anã' as a function of doses of $\mathrm{K}$ and $\mathrm{Mg}$ applied to the soil. 
and storage tissues, decreasing the $\mathrm{Mg}$ concentration throughout the plant.

In the second production cycle of the banana plant, it was observed that increase in doses of $\mathrm{K}$ applied to the soil reduced the leaf $\mathrm{Mg}$ content in a linear manner (Figure 3b). Similar results were found by Silva et al. (2008) and Ganeshamurthy et al. (2011), who observed that with increase in the $\mathrm{K}$ levels in the soil, the leaf $\mathrm{Mg}$ content decreased. Decrease in the $\mathrm{Mg}$ content in the leaf tissues may be attributed to the competitive effect among these nutrients (Malavolta, 2006).

In the first cycle, with increase in the doses of $\mathrm{K}$ there was increase in the Ca leaf content in a linear manner (Figure 4a), and in the second cycle, with increase in doses of $\mathrm{K}$ applied to the soil there was an increase in $\mathrm{Ca}$ leaf content in a quadratic manner (Figure 4b). Vitti et al. (2006) cite that $\mathrm{Ca}$ is taken up by the roots as $\mathrm{Ca}^{2+}$, and its uptake may be reduced by high concentrations of $\mathrm{K}^{+}$in the plant growth medium. According to Manica (1997) uptake of $\mathrm{Ca}$ by plants is a passive process, increasing its content to the extent that the plant ages.

In the absence of potassium fertilization and with an increase in the doses of $\mathrm{Mg}$, the B content in the banana leaves increased in a linear manner in the first cycle. In the second cycle, with increase in the doses of $\mathrm{K}$, there was a reduction of $\mathrm{B}$ leaf content (Figure 5a and 5b). Echer et al. (2009), working with top dressing fertilization with boron and potassium in regard to nutrition and yield of sweet potato, observed that the $\mathrm{B}$ leaf content increased in accordance with increase in the dose of $\mathrm{B}$ and of $\mathrm{K}$, suggesting a synergistic effect between $\mathrm{K}$ and $\mathrm{B}$ because the addition of one allowed utilization of the other. According to Flora et al. (2010), excess of $\mathrm{K}$ may cause inhibition in B uptake, and may induce or contribute to deficiency of this nutrient.
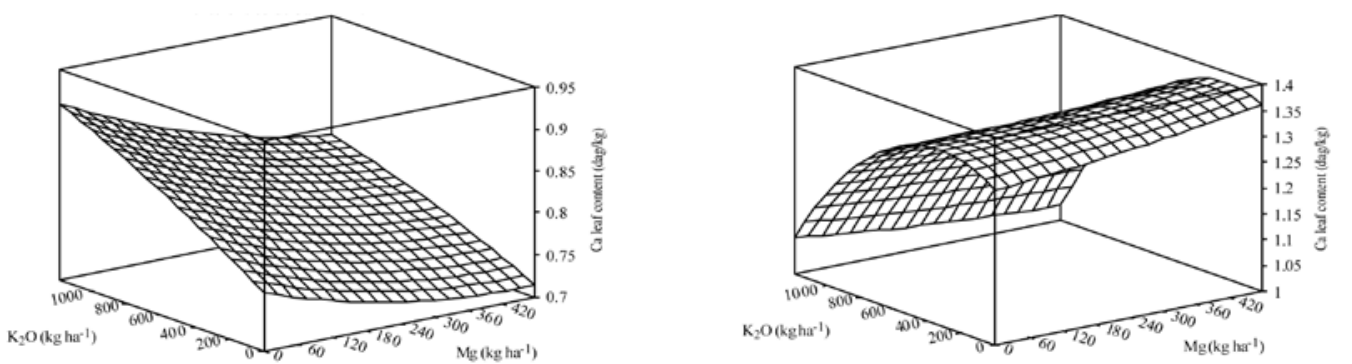

Figure 4. Ca leaf content in the first cycle (a) and in the second cycle (b) of the banana cv. 'Prata Anã' as a function of doses of $\mathrm{K}$ and $\mathrm{Mg}$ applied to the soil.
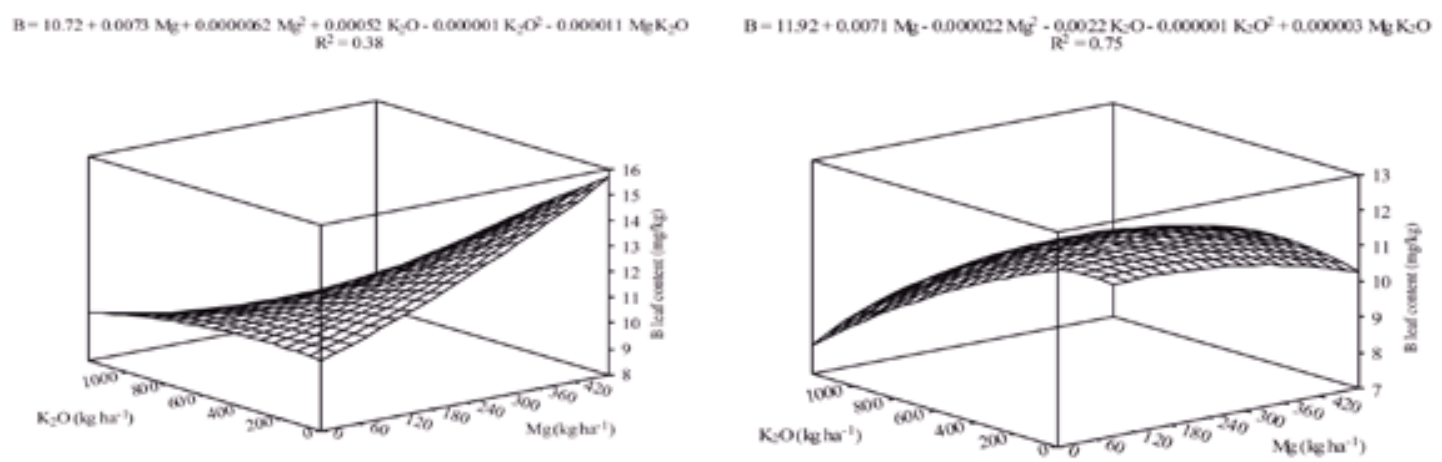

Figure 5. B leaf content in the first cycle (a) and in the second cycle (b) of the banana cv. 'Prata Anã' as a function of doses of K and $\mathrm{Mg}$ applied to the soil. 


\section{Conclusions}

The application of $\mathrm{K}$, regardless of the cycle under consideration, increased the weight of the banana bunch, the number of fruits per bunch, the number of hands per bunch, and the weight and diameter of the middle fruit of the banana plant.

The application of $\mathrm{Mg}$ to the soil decreased the weight of the bunch with increases in the doses of $\mathrm{Mg}$ in the first cycle.
With increased of doses of $\mathrm{K}$, the $\mathrm{K}$ and $\mathrm{Ca}$ content increased, reducing the $\mathrm{Mg}$ and $\mathrm{B}$ leaf content of the banana cv. 'Prata Anã'.

\section{Acknowledgment}

CNPq - National Council for Scientific and Technological Development and CAPES -Coordination of Improvement of Higher Education Personnel, by granting scholarships and financial aid for the conduction of the study and publication of the scientific paper.

\section{Literature Cited}

Borges, A.L.

2004. Calagem e adubação. In: Borges, A.L.; Souza, L.S. (Eds.) O cultivo da Bananeira. Cruz das Almas: EMBRAPA. pp. $32-43$.

Brasil, E.C.; Oeiras, A.H.L.; Menezes, A.J.E.A.; Veloso, C.A.C. 2000. Desenvolvimento e produção de frutos de bananeira em resposta à adubação nitrogenada e potássica. Pesquisa Agropecuária Brasileira. Brasília. 35: 2407-2414.

Echer, F.R.; Dominato, J.C.; Creste, J.E.; Santos, D.H. 2009. Fertilização de cobertura com boro e potássio na nutrição e produtividade da batata doce. Horticultura Brasileira, Brasília. 27: 171-175.

EMBRAPA - Empresa Brasileira de Pesquisa Agropecuária. 1999. Sistema brasileiro de classificação de solos. Brasília: EMBRAPA/ Centro Nacional de Pesquisa do Solo. 412 p.

EMBRAPA - Empresa Brasileira de Pesquisa Agropecuária. 1990. Informática Agropecuária. Programa SOC - software científico: versão 2.1. Campinas: Embrapa.

Faquin, V. 2005. Nutrição Mineral de Plantas. Lavras: UFLA/FAEPE, $183 \mathrm{p}$.

Flora, A.P.; Brugger, B.P.; Santos, F.R.; Couto, F.P.; Negrão, R.G. 2010. Estresse nutricional em plantas. Available at: $<\mathrm{http}: / /$ www.webartigos.com/articles/34518/1/ESTRESSENUTRICIONAL-EM-PLANTAS/pagina1.html>. Accessed: August 21, 2011.

Ganeshamurthy, A.N.; Satisha, G.C. Prakash, P.A.T.I.L.

2011. Potassium nutrition on yield and quality of fruit crops with special emphasis on banana and grapes. Karnataka Journal Agriculture Science. 24: 29-38.
Malavolta, E.; Vitti, G.C.; Oliveira, S.A.

1997. Avaliação do estado nutricional das plantas: princípios e aplicações. Piracicaba: POTAFOS, 201 p.

Malavolta, E.

2006. Manual de nutrição de plantas. São Paulo: Ed. Agronômica Ceres, $638 \mathrm{p}$.

Maia, V.M.; Salomão, L.C.; Cantarutti, R.B.; Venegas, V.H.A.; Couto, F.A.D.

2003. Efeitos de doses de nitrogênio, fósforo e potássio sobre os componentes da produção e a qualidade de bananas 'Prata Anã' no Distrito Agroindustrial de Jaíba. Revista Brasileira de Fruticultura, Jaboticabal. 25: 319-322.

Manica, I.

1997. Fruticultura tropical 4: Banana. Porto Alegre: Cinco Continentes, $485 \mathrm{p}$.

Silva, J.T.A.; Borges, A.L.; Malburg, J.L.

1999. Solos, adubação e nutrição da bananeira. Informe agropecuário, Belo Horizonte. 20: 21-36.

Silva, J.T.A.; Borges, A.L.; Carvalho, J.G. Damasceno, J.E.A. 2003. Adubação com potássio e nitrogênio em três ciclos de produção da bananeira cv. 'Prata Anã'. Revista Brasileira de Fruticultura, Jaboticabal. 25: 152-155.

Silva, J.T.A. Borges, A.L.

2008. Solos, nutrição mineral e adubação da bananeira. Informe Agropecuário, Belo Horizonte. 29: 25-37.

Silva, J.T.A.; Silva, I.P.; Moura Neto, A.; Costa, E.L.

2008. Aplicação de potássio, magnésio e calcário em mudas de bananeira 'Prata Anã'(AAB). Revista Brasileira de Fruticultura, Jaboticabal. 30: 782-786.

Vitti, G.C.; Lima, E.; Cicarone, F.

2006. Cálcio, Magnésio e Enxofre. In: Fernandes, M.S. (Ed.). Nutrição Mineral de Plantas. Viçosa: SBCS, pp. 299-322. 